\title{
Master of the clinical trial: 2014 Canada Gairdner Wightman Award winner Dr. Salim Yusuf
}

$\mathrm{T}$ he boy was a good student but tended to coast at times. When he took biology in Grade 9, he barely passed his first exam. Salim, you can do so much better, his teacher told him. You are being lazy.

Accepting the implied challenge, the young pupil decided to show his teacher just how much better he could do. He studied hard, and not just the curriculum. He got his hands on university textbooks and studied them too. On the next test, he received an extraordinarily good mark.

You see, Salim, his teacher said. Just look what you are capable of.

What Salim Yusuf also discovered, in addition to that brief glimpse of his potential, was that science is fascinating. He continued to read widely, beyond what was required or expected of him, and he continued to excel, his coasting days fading into memory.

When he finished high school in Kochi, a port city on India's west coast, Yusuf applied to medical schools. It was his father, a personnel manager for an oil refinery, who encouraged him to pursue medicine. And it was his father's heart attack - for which there were no treatments in the early 1970 s - that provided the motivation. The experience had been terrifying, leaving Yusuf and his mother, brother and sister in a state of bewilderment.

The good news was that his father recovered. The bad news was that none of the medical schools Yusuf applied to appeared to reciprocate his interest. As the rejection letters piled up, he almost gave up and considered pursuing another field of study. Finally, however, an invitation for an interview arrived in the mail from St. John's Medical College in Bangalore.

Carrying a small suitcase and just enough money for a return trip, Yusuf departed for Bangalore. His expectations were low. But the interview went better than he expected, and he was not only accepted - he was to start classes right away. The few changes of clothing

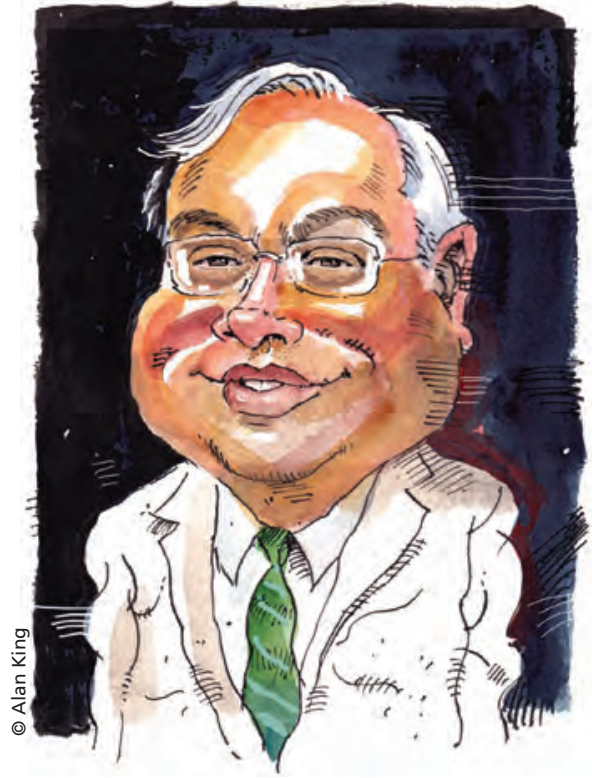

Dr. Salim Yusuf is the 2014 recipient of the Canada Gairdner Wightman Award.

he brought had to last a month, until he could return home to fetch more.

Later in his medical education, during a rural posting in the village of Mallur, Yusuf conducted his first research experiment. "I didn't call it a research project," he recalls. "I was just curious. I saw a problem and tried to solve it."

The problem was very high rates of diarrheal diseases. Yusuf did a survey of the nine wells in the village, finding that a few were next to cow sheds or in some other unhygienic location. He shipped water samples to a public health laboratory, received the bacteria counts, determined how much chlorine was required for each well and asked the village headman if he could treat the water.

$\mathrm{He}$ was granted permission but asked to perform the task after the women in the village had finished drawing water for the day, to avoid unnecessary worry. So Yusuf waited until evening and, with a dozen or so high school students on bicycles, began chlorinating the wells.

Just as they were finishing up four hours later, a group of women came to use the final well on the list. Oh no, the women said. You've spoiled the water. 
In a moment of bravado, Yusuf pulled the bucket from the well and drank from it. Unfortunately, it still contained concentrated chlorine, so he spat the water out onto the ground.

"That set back my public health effort," says Yusuf, chuckling at the memory. "The good news is the rates of diarrheal diseases just plummeted after that."

During his next rural posting, in Munnar, Yusuf learned another valuable lesson. He already knew that data were important, but came to see that the answer to a health question sometimes lies in the context rather than numbers.

He wanted to know why the rates of salpingectomies were so much higher in Munnar than for vasectomies, a much simpler procedure. Surveys were
Yusuf remains particularly good at asking important questions, according to Dr. Jack Hirsh, professor emeritus of hematology and thromboembolism at McMaster University in Hamilton, Ontario. "Salim and his team may spend six months or even a year discussing the questions and how best to answer them," says Hirsh. "That's one reason so many of the projects that Salim has been involved with have been game-changers and have made a huge difference."

Two influential concepts that Yusuf helped introduce to the research community during his time at Oxford were the properly conducted meta-analysis and the large, simple clinical trial.

At the time, most clinical trials weren't large enough to prove that a

\section{"Large is the key thing; simple is the vehicle."}

conducted and wishy-washy answers received. Finally, a man in the village told him the truth. If the wife of a man who had a vasectomy became pregnant via an affair, that man would lose face in the village.

"No quantitative survey could get us that information," says Yusuf. "Of course, we weren't going to cure extramarital sex."

These initial and rudimentary forays into research, Yusuf believes, helped him win a Rhodes Scholarship to study at the University of Oxford in the United Kingdom. It was there that he first met real scientists, including Dr. Richard Peto, a world-renowned researcher and professor of medical statistics and epidemiology who would become his mentor and collaborator.

Many of the medical research principles he learned from Peto in the late 1970s still guide Yusuf today, as he conducts some of the largest studies in the world on cardiovascular disease. Three principles, in particular, stand out. One: look for a disease's burden and work in the region where that burden is largest. Two: you not only have to get the big picture right; you also have to get the details right. Three: ask an important question and answer it reliably. treatment worked. A bit of good luck made a treatment seem better than it was. A bit of bad luck made it seem worse that is was. So, instead of enrolling thousands of people in their clinical trials, Yusuf and Peto enrolled tens of thousands of people. But the only way to make that feasible, and affordable, was to keep the trial simple. measuring only a few outcomes.

"Large is the key thing; simple is the vehicle," says Yusuf.

After completing his training in cardiology at Oxford in 1984, Yusuf moved to Bethesda, Maryland, to work for the National Institutes of Health, where he conducted influential trials on heart failure. In 1992, he became the director of cardiology at McMaster University and, a few years later, founded the Population Health Re search Institute. Now 61 years old, Yusuf has published hundreds of studies and is among the top $1 \%$ of cited medical researchers in the world.

There are several reasons why Yusuf has been so successful in repeatedly producing high-impact research, according to Dr. David Sackett, professor emeritus of clinical epidemiology and biostatistics at McMaster UniverPose a good question and focus on sity. As a clinical cardiologist, Yusuf has seen first-hand the devastating effects of cardiovascular disease and is motivated to find solutions. He is a collaborative genius, says Sackett, and will travel all over the world to convince respected researchers and clinicians to participate in international clinical trials. Yusuf is also a sophisticated methodologist, able to coordinate very large clinical trials from concept to completion.

"He knows the types of investigations that are required to demonstrate that something works," says Sackett. "He is the master of the clinical trial."

It was announced Mar. 26 that Yusuf would receive the 2014 Canada Gairdner Wightman Award for his outstanding career in biomedical research. In April, he was inducted into the Canadian Medical Hall of Fame. These are but two of many honours Yusuf has received for his work, which has changed how cardiovascular disease is prevented, treated and managed.

"The thing that probably pushes him more than anything else is his concern and abiding dismay over the burden of disability and untimely death from cardiovascular disease that he thinks is potentially preventable," says Sackett. "He is motivated by human suffering."

Outside of work, Yusuf's main interest is family. He is married and has three children: one a pediatrician, another in medical school, the youngest still "finding herself." He occasionally finds time to read The Economist or a book on history or philosophy, squeezing in some fiction by Salman Rushdie or V.S. Naipaul now and then.

Though he no longer plays field hockey, as in his younger days, he does play a little golf. "The word "play' may be giving it a high level of respectability that it doesn't deserve," he says. "My wife calls it a very inefficient way of chopping grass." - Roger Collier, CMAJ

CMAJ 2014. DOI:10.1503/cmaj.109-4771

\section{More News online}

To read more CMAJ news articles, visit cmaj.ca/site/home/news.xhtml 